\title{
PSYCHOLOGICAL-PEDAGOGICAL ASPECTS OF STUDENTS' ADAPTATION IN RUSSIAN UNIVERSITIES
}

\author{
Bogdan Ershov ${ }^{1}$, Olga Shmyreva ${ }^{2}$ \\ ${ }^{1}$ Doctor of Historical Sciences, Professor, Voronezh State Technical University, 20 years of October \\ street, 84, Voronezh, Russia, E-mail: bogdan.ershov@yandex.ru \\ ${ }^{2}$ Candidate of Psychological Sciences, Associate Professor, Voronezh State University of \\ Engineering Technologies, Revolutsii Street, 19, Voronezh, Russia, \\ E-mail: oishmyreva@rambler.ru
}

\begin{abstract}
The article discusses effective ways to improve the quality of psychological preparation of students for pedagogical activity, where an important criterion is the special training of future teachers in psychologically meaningful pedagogical design. The method of teaching is to create conditions for the formation of a certain psychodidactic model of the lesson in the student's consciousness. An educational and professional constructive task intended for pedagogical practice can act as a means of creating these conditions.
\end{abstract}

Keywords: education, practice, student, society, country.

\section{INTRODUCTION}

The modern educational paradigm imposes new requirements on the teacher: the restructuring of educational values and standards, curricula creates an objective need for the teacher to reconsider his own approach to teaching and educating a younger person. The organization of the educational process itself appears no longer as a sophisticated management of the student's activities, not as the formation of his personality set from the outside, but as a developing interaction of the personalities of the teacher and the child.

Apparently, the most vividly creative nature of the teacher's activity is manifested at the stage of developing ideas on how to build a future lesson so that it is a "cell" of the developing system, what conditions need to be created so that schoolchildren become genuine subjects of teaching. The solution of these tasks occurs at school mainly due to the high-quality development of lessons by the teacher. This means that the creative activity of the teacher is realized to the greatest extent in the process of pedagogical construction.

If we consider the creation of conditions for the development and self-development of a growing person to be the highest goal of pedagogical activity, then the well-known requirement for the psychologization of pedagogical activity is perceived as quite natural. In this regard, in this study we are talking about psychologically meaningful pedagogical construction.

\section{METHODOLOGY}

The methodological basis of the study was made up of: regulatory documents of the federal and 
departmental levels the Law on Education of the Russian Federation, the regulations on secondary vocational educational institutions, state educational standards of secondary vocational education, the idea of activity as the basis of general psychological and professional development of a person (B.G.Ananyev, A.N.Leontiev, S.L.Rubinstein), the model of competence research by L.M. Spencer.

\section{DISCUSSION}

Improving the educational process of higher education is one of the central problems in research on professional pedagogy.

The fundamental foundations of the educational process are covered in the works of S.I. Arkhangelsky, V.I. Baydenko, V.P. Bespalko, A.A. Verbitsky, B.S. Gershunsky, E.N. Gusinsky, O.V. Dolzhenko, V.I. Zagvyazinsky, I.A. Zimnaya, M.V. Klarin, V.V. Kraevsky, N.V. Kuzmina, Yu.N. Kulyutkin, I.Ya. Lerner, B.T. Likhachev, P.I. Pidkasistogo, V.A. Slastenin, N.F. Talyzina et al .

Innovations at the university were the subject of research by A.B. Balakhonov, G.V. Belaya, A.B. Berestov, B.A. Bordovsky, N.V. Borisova, V.I. Ivanova, A.M. Novikov, B.I. Pisarenko, Z.S. Sazonova, O.A.Sviridova, Yu.G. Tatura, V. D. Shadrikov, etc. The works of V.I. Andreev, A. E. Bogoyavlenskaya, E.V. Bondarevskaya, A.A. Grachev, T.A. Denisova, J1.B. Zanina, I.A. Zimnaya, C.B. Kulnevich, E.A. Savchenko, V.V. Serikov, G.N. Serikov, I.A. Ste-tsenko, I.S. Yakimanskaya and others are devoted to humanization and personalization. Informatization of the educational environment was studied in the studies of A.H. Ardeev, A.I. Artyukhina, R.Yu. Gurnikovskaya, I.I. Dzege-lenoka, I.G. Zakharova, M.B. Lebedeva, M.V. Litvinenko, E.V. Lobanova, L.Yu. Monakhova, E.S. Polat, G.P. Chepurenko, etc. Quality management of education at the university is represented by the research of H.A. Vasilyeva, E.Y. Vasilyeva.

Thus, the analysis of the educational practice of universities and numerous scientific and pedagogical studies of their modernization revealed the need to develop conceptual foundations for the formation of the educational process of the university as an open self-organizing system in conditions of instability and dynamism of the external environment, which determined the problem of this study.

\section{RESULTS}

The study of the readiness of first-year students to adapt at the university was considered as a certain sequence of stages: motivational-adaptive, the purpose of which was to determine the system of motives for professional self-determination; and reflexive-transformative, as a result of which the experience of independent and collective work was formed among first-year students, and the criteria of readiness were determined (low - socio-psychological, medium - scientific-pedagogical, high - professional).

According to the criteria of readiness, pedagogical tasks and the content of work were determined to increase the levels of readiness, and a structural model of successful adaptation of first-year students to the educational process of higher school was proposed.

Four interrelated variables were noted as the design unit of the educational situation: the content of the subject, structured in accordance with the learning objectives; conditions that organize the assimilation of educational content and generalized methods of educational activity; the system of educational interactions of the teacher with students and students with each other; the dynamics of these variables in their relationship throughout the learning process.

Considering the adaptation of first-year students to the educational process of higher education, it is possible to determine objective and subjective criteria of adaptation, where objective include productive activity, real position in the team, academic performance, authority, and subjective - personal satisfaction and attitude to various aspects and conditions of activity and communication, as well as the relationship of the individual to himself.

The adaptation of first-year students to the university is determined by three levels: high, which is characterized by an optimal combination of adaptive strategies aimed at mutual change of the personality and the environment; medium, determined by the choice of wait-and-see strategies and low level of adaptation, which is characterized, as a rule, by withdrawal from the environment and isolation.

The factors contributing to the psychological and pedagogical adaptation of first-year students to the educational process of higher education are divided into three blocks: sociological, psychological and pedagogical.

A number of factors have been identified, the complex action of which contributes to the development of the motivational readiness of the subject for a new educational activity, where there is an objective coincidence 
of the motivational orientation of students for personal development with the target settings of the modern education system; personal and individual orientation of the psychological training system, which is built taking into account the specifics of the prevailing real motivation of the subjects of professionalization; purposeful actualization of the action of system-forming factors in the form of motivational-target relations, psychological mechanisms of motivational authorization of activities, as well as increasing the internal motivation of the subject by enriching the content of the activity, which is possible at the level of its conceptual model, operational and regulatory components.

The construction of the scientific and theoretical nature of the educational activity of the university, pedagogical support and pedagogical support of first-year students during the adaptation period is interpreted as a certain system of means that ensure the self-realization of students in the educational process. The levels of readiness of first-year students to adapt at the university are considered as an active state of personality that causes attitudes to professional situations and tasks, as a prerequisite for purposeful activity, its regulation, stability and effectiveness in the form of a sequence of stages: motivational-adaptive and reflexive-transformative.

As criteria of readiness for adaptation at the university, the following were identified: socio-psychological, scientific-pedagogical and professional levels, pedagogical tasks and the content of work with first-year students aimed at increasing the level of adaptation to the educational process of higher school were determined.

\section{CONCLUSION}

A number of factors, the complex action of which contributes to the development of the motivational readiness of the subject for a new educational activity, where there is an objective coincidence of the motivational orientation of students of personal development with the target settings of the modern education system, have a significant impact on the readiness of first-year students to adapt. Moreover, the initial period of study at the university, the most difficult and responsible, acts as the spatial-temporal continuum of research.

The most adequate means and sufficient basis for solving the problem of adaptation is the development and implementation of a system of pedagogical conditions, which are characterized as an integral pedagogical process, sequence, arrangement of its parts, causing a continuous increase in functions in the development of the student body and personality as a whole. The most important role in the organization of the adaptation process of first-year students is played by the creation of a favorable psychological and pedagogical climate in the group, at the faculty, at the university, as well as timely diagnosis, psychological assistance, support and pedagogical support of the student.

\section{REFERENCE LIST}

Belova T.V. (1991) Humanitarization and computerization as a way of updating education in developed countries. Science, production. M. Pp. 124-131. (in Russ).

Chepurnykh E.E. (2002) Legal support of innovation activity in the field of Russian education. Innovations in education. №. 1. Pp. 4-10. (in Russ).

Chernilevsky D.V., Filatov O.K. (1996) Technology of higher education. Educational publication. M.: "Forwarder". 288 p. (in Russ).

Ershov B.A. (2010) The Russian Orthodox Church and secular power in the Voronezh province in the XIX early XX centuries. GOU VPO "Voronezh State Technical University". Voronezh. 167 p. (in Russ).

Ershov B.A. (2010) The system of spiritual education in Voronezh province in the 19th century. Education and Society. №. 5 (64). Pp. 105-108. (in Russ).

Ershov B.A., Fursov V.N. (2018) The Russian Church in the State Mechanism of Russia. Bulletin SocialEconomic and Humanitarian Research. № 1. Pp. 32-37. (in Engl).

Ershov B.A., Perevozchikova L.S., Romanova E.V. (2019) Globalization and Intensification of Spiritual Values in Russia in the Philosophical Aspect. 6th International Conference on Education and Social Sciences Abstracts \& Proceedings. Pp. 208-212. (in Engl). 
Ershov B.A., Perevozchikova L.S., Romanova E.V., Ashmarov I.A. (2019) The Concept of Spirituality in Social Philosophy. Smart Innovation, Systems and Technologies. T. 139. Pp. 688-694. (in Engl).

Filippova E.F. (2001) Features of quality management of education in the pedagogical Lyceum. The role and place of innovative boarding schools in the modern education system. Ufa. Pp. 50-57. (in Russ).

Kozlenkova N.V. (1990) Automated training systems: Moskovok s-x Academy. Moscow: Publishing House of the Ministry of Agriculture. 24 p. (in Russ).

Kozoriz N.L. (1993) Information technologies and their implementation in the military-technical policy of Russia: Dis. cand. philos. sciences. 194 p. (in Russ).

Lednev V.S. (1991) The content of education: essence, structure, prospects. M.: Higher school. 223 p. (in Russ).

Mikheev V.I. (1990) Theory and methodology of checking the quality of students' knowledge using a computer. Dis...Doctor of pedagogical Sciences in the form of scientific. 46 p. (in Russ).

Okhlopkov A.N., Koroleva M.V., Klochkov I. A. (1991) New information technologies in the teaching of social sciences: Methodological recommendations. Moscow: VPA. 76 p. (in Russ).

Romanova E.V., Perevozchikova L.S., Ershov B.A. (2017) The Lifestyle of the Human Being in the Information Society. 3rd International Conference on Advances in Education and Social Sciences Proceedings of ADVED Pp. 950-954. (in Engl).

Shcherbo I. (2000) High quality education: a product that we can offer to the consumer. The headmaster of the school. №. 9. Pp. 8-18. (in Russ).

Shishov S.E., Kalney V.A. (2000) School: monitoring the quality of education. 316 p. (in Russ).

Yakovlev E.V. (1999) Theoretical foundations of quality management of education in higher education. Chelyabinsk: Publishing house of ChSPU. 163 p. (in Russ). 